\title{
Beyond "Public Concern": New Free Speech Standards for Public Employees
}

\author{
D. Gordon Smith $\dagger$
}

\section{INTRODUCTION}

When the state uses its position as an employer to regulate the speech of public employees, ${ }^{1}$ First Amendment questions arise that are more complicated than those typically posed in cases involving freedom of speech. ${ }^{2}$ In employee speech cases, the state and individual both play dual roles. The state is at once the sovereign and the employer; the individual, a citizen and an employee. The presence of an employment relationship provides the state with greater incentive and greater ability to restrict an individual's speech. The state's increased incentive to restrict speech is rooted in efficiency concerns: like all employers, the state needs to manage its operations efficiently, and efficient management requires some control over employee speech. ${ }^{3}$ The state's increased ability to restrict speech arises from the availability of employment-related sanctions: as sovereign, the state restricts speech through injunctions, ${ }^{4}$

$\dagger$ B.S. 1986, Brigham Young University; J.D. Candidate 1990, The University of Chicago.

1 The term "public employees" is used in this Comment to denote non-civil service employees at the federal, state, and local levels. Civil servants, who are hired based on competitive examinations under an established civil service system, are subject to special speech regulations beyond the scope of this Comment. See, for example, The Hatch Political Activity Act, 5 USC $\$ 7324$ (1982). On the other hand, civil servants receive certain statutory rights not accorded public employees. See, for example, The Lloyd-LaFollette Act, 5 USC $\S$ 7513 (1982) (civil servant may not be fired without "cause").

2 "Congress shall make no law ... abridging the freedom of speech, or of the press; ..." US Const, Amend I. These prohibitions were extended to the states through the Due Process Clause of the Fourteenth Amendment. See Fiske v Kansas, 274 US 380 (1927).

${ }^{3}$ Although the speech of ordinary citizens may also disrupt government efficiency (see Greer $v$ Spock, 424 US 828, 836 (1976)), public employee speech poses a much greater threat to government operations. Public employees have greater access to inside information about the government and spend more time at government facilities. In addition, statements of employees will be given greater credence by the public than statements of non-employees (indeed, the speech of an employee might even appear to the public to be the speech of the government office for which the employee works), and may erode vital public support.

- See, for example, Pittsburgh Press Co. v Pittsburgh Commission on Human Relations, 413 US 376 (1973) (newspaper prohibited from carrying "help-wanted" advertisements in sex-designated columns). 
damages, ${ }^{5}$ and criminal penalties, ${ }^{6}$ but as employer it may circumvent the judicial process and sanction public employees directly with either disciplinary action or dismissal.

Until the 1950s, the Supreme Court had held that when the state disciplines or dismisses public employees for their speech it acts just like a private employer, and hence is not subject to the restrictions that the First Amendment places upon its acts as sovereign. ${ }^{7}$ During the 1950 s and 1960 s, the Court gradually acknowledged constitutional claims by public employees. ${ }^{8}$ And, in 1967, the Supreme Court recognized in Pickering $v$ Board of Education ${ }^{9}$ that employment-imposed restrictions on employee speech may violate the First Amendment. This Comment contends, however, that the treatment of employee speech set forth in Pickering and its progeny still permits the state to unduly restrict the free speech rights of public employees.

This Comment begins with a review of the major Supreme Court decisions in the area. It then illustrates the difficulties engendered by these decisions, particularly the problems arising from the so-called "public concern" threshold test. The Comment then proposes a new structure for First Amendment analysis of public employee speech. The structure features a new threshold test that would afford standard First Amendment protection to all employee speech except speech that is "related" to employment. Speech sufficiently related to employment to merit attention from the state as employer would be subject to a new sequence of burdens of proof, designed to better respect the reasons for regulating-and, in some cases, for tolerating-disruptive employee speech.

\footnotetext{
5 See, for example, Dun \& Bradstreet $v$ Greenmoss Builders, 472 US 749, 756-57 (1985) (compensatory and punitive damages awarded in defamation action).

- See, for example, New York v Ferber, 458 US 747 (1982) (bookstore owner found guilty of felony for selling material depicting "sexual performance" by minors).

7 Justice Holmes's famous aphorism, written while he was serving on the Massachusetts Supreme Court, aptly characterizes this view: "The petitioner may have a constitutional right to talk politics, but he has no constitutional right to be a policeman." McAuliffe $v$ Mayor of New Bedford, 155 Mass 216, 29 NE 517, 517 (1892).

s See Wieman v Updegraff, 344 US 183 (1952) (invalidating on due process grounds an Oklahoma statute requiring state employees to take a loyalty oath). See also Keyishian $v$ Board of Regents, 385 US 589, 605 (1967) (rejecting the notion that public employment "may be conditioned upon the surrender of constitutional rights which could not be abridged by direct government action").
}

391 US 563 (1968). 


\section{The Evolution of Free Speech Rights for Public EMPLOYEES}

In the leading case of Pickering $v$ Board of Education, public schoolteacher Marvin Pickering was fired for a letter he had written to the editor of the local newspaper; the letter criticized the school board for its handling of revenue proposals and for its allocation of funds between the school's academic and athletic programs. Pickering sued for reinstatement, claiming First Amendment protection.

The Supreme Court recognized the case as an opportunity to establish the broad parameters of a constitutional standard for state regulation of public employee speech. Two extreme approaches presented themselves. At one end was the Illinois courts' holding that public schoolteachers relinquish their First Amendment rights when they accept employment; an individual has no right to be a teacher, the courts reasoned, and accepts the privilege of employment subject to the conditions specified by government. ${ }^{10}$ At the other extreme was the view that public employees should enjoy the same latitude in speech rights as ordinary citizens.

The Court rejected both views, recognizing that one unnecessarily abridged the First Amendment rights of public employees, while the other failed to acknowledge the state's increased interest in regulating the speech of its employees. ${ }^{11}$ Instead, the Court surmised that the state possesses an interest as employer in limiting the speech of its employees that is not insuperable, but that is

\footnotetext{
${ }^{10}$ See Pickering $v$ Board of Education, 36 Ill 2d 568, 225 NE2d 1, 6 (1967) ("[Plaintiff] is no more entitled to harm the schools by speech than by incompetency, cruelty, negligence, [or] immorality. ... By choosing to teach in the public schools, Plaintiff undertook the obligation to refrain from conduct which in the absence of such a position he would have an undoubted right to engage in."). The Illinois courts were following the traditional view, discussed in note 7 and accompanying text. In Pickering, the Supreme Court said that the rights-privilege distinction underlying this view had been "unequivocally rejected" in prior decisions. Pickering, 391 US at 568, citing: Wieman, 344 US 183; Shelton v Tucker, 364 US 479 (1960); and Keyishian, 385 US 589. For a discussion of these and other cases, see Casenote, Infringement upon Public Employees' Right to Speak on Matters of Public Concern, 55 Tenn L Rev 175, 178-83 (1987).

11 Pickering, 391 US at 568. For another view, see Richard A. Epstein, Unconstitutional Conditions, State Power, and the Limits of Consent, 102 Harv L Rev 4, 67-73 (1988): [A] court can simply ask whether the kinds of restrictions that the government seeks to impose on its own employees are similar to those that private firms in competitive labor markets impose on employees engaged in similar activities. Perhaps some positions in government are so unique that no private analysis applies, but even in this context, the large number of government employees may help create a competitive labor market.
}

Id at 68 . 
greater than its interest as sovereign in limiting the speech of its cicizens. ${ }^{12}$ The goal, the Court wrote, must be to "arrive at a balance between the interests of the [employee], as a citizen, in commenting upon matters of public concern and the interest of the State, as an employer, in promoting the efficiency of the public services it performs through its employees."13 The result has been called "Pickering balancing," which permits restriction of employee speech less valuable than the disruption it causes.

The Court implicitly adopted a broad definition of disruption in Pickering. An employee's speech disrupts the efficiency of a public employer when it: (1) adversely affects the employee's own performance; (2) disturbs harmony and discipline in the workplace; (3) interferes with the regular operation of the government office or agency; or (4) undermines public trust in the office or agency by disseminating false information in such a way that renders the government employer unable to effectively counter the employee's speech. ${ }^{14} \mathrm{~A}$ broad definition of disruption enables the government employer to restrict employee speech that directly impairs government efficiency (by, for example, interrupting the normal office routine or distracting government workers) as well as speech that reveals the employee's own incompetence, ${ }^{15}$ creates "disharmony" among other workers, ${ }^{16}$ or demonstrates disloyalty. ${ }^{17}$

Even this broad definition of disruption, however, protects employee speech that does not affect the employer in any way. Indeed, in Pickering itself the Court found that the teacher's speech

12 Pickering, 391 US at 568.

13 Id.

14 Id at 569-73. Compare Cass R. Sunstein, Government Control of Information, 74 Cal L Rev 889, 919 (1986): "In its capacity as employer, the government has two interests that come up in many contexts: the desire to avoid disruption of working relationships and the need to set out a uniform official position." Professor Sunstein also points out that the government has an "institutional interest in exaggerating the extent to which speech that is critical of current policies, or that discloses information, interferes with the employment relationship." Id.

${ }_{16}$ See Lefcourt $v$ Legal Aid Society, 445 F2d 1150, 1153 (2d Cir 1971) ("Lefcourt's right to freedom of speech did not preclude [his employer] from concluding on the basis of Lefcourt's views that he was unable or unwilling to implement various policies of the [employer].").

${ }^{16}$ See Phillips $v$ Adult Probation Dept., 491 F2d 951, 955 (9th Cir 1974) (probation officer did not have a First Amendment right to display a poster on his office wall depicting fugitives from justice in a favorable light, since it "would impair the efficiency of the Department through dissension and disharmony among the employees.").

17 See Sprague v Fitzpatrick, 546 F2d 560, 565 (3d Cir 1976) (Assistant District Attorney who was fired after demanding the resignation of the District Attorney could not be reinstated because there had been an "irreparable breach of confidence" between the superior and the employee). 
was not disruptive at all, and concluded that when an employee's speech does not disrupt government efficiency, it should be evaluated under normal First Amendment standards; that is, the employee should be treated as though he were speaking as an ordinary citizen. ${ }^{18}$ The Court observed that if an ordinary citizen had written the letter at issue in Pickering, it would have been judged under the First Amendment standards for libel. Consequently, the state could not dismiss Pickering from public employment "absent proof of false statements knowingly or recklessly made by him."19

The Supreme Court did not have occasion to apply Pickering balancing until fifteen years later, in Connick v Myers. ${ }^{20}$ In Connick, New Orleans District Attorney Sheila Myers prepared and circulated within the office a questionnaire soliciting the views of fellow employees concerning, among other things, office transfer policy, the need for a grievance committee, and the level of confidence in supervisors. The circulation of the questionnaire followed failed attempts to convince the District Attorney, Harry Connick, to revoke his plan to transfer her to a different office. Connick considered the questionnaire an act of insubordination and fired $\mathrm{My}$ ers. Myers sued, alleging that she was improperly discharged for speaking as a citizen. The lower courts agreed. But the Supreme Court reversed, holding that the lower courts had "misapplied" Pickering. ${ }^{21}$

18 Pickering, 391 US at 572-73. The Court's conclusion meant that "Pickering balancing" was formulated but never actually applied in Pickering itself; later Supreme Court cases would have to show how balancing would be done. See the discussion in text at note 20 of Connick $v$ Myers, 461 US 138 (1983).

19 Pickering, 391 US at 574. Because Pickering criticized public officials, the Court applied the New York Times standard. See New York Times Co. v Sullivan, 376 US 254 (1964). The Court declined to adduce different constitutional standards for different state sanctions:

While criminal sanctions and damage awards have a somewhat different impact on the exercise of the right to freedom of speech from dismissal from employment, it is apparent that the threat of dismissal from public employment is nonetheless a potent means of inhibiting speech.

Pickering, 391 US at 574.

${ }_{20} 461$ US 138 (1983). In the interm, three cases allowed the Court to define the limits of Pickering without explicitly balancing. In Perry $v$ Sindermann, 408 US 593, 596-98 (1972), the Court ruled that the First Amendment protects public employees even absent tenure or a contractual right to reemployment. In Mt. Healthy City Board of Education $v$ Doyle, 429 US 274, 285 (1977), the Court held that a public employer may justify disciplinary action against an employee by showing that the action would have been taken even in the absence of the protected speech. And in Givhan $v$ Western Line Consolidated School District, 439 US 410, 414 (1979), the Court held that an employee does not forfeit "protection against governmental abridgement of freedom of speech if [she] decides to express [her] views privately rather than publicly."

${ }^{21}$ Connick, 461 US at 142. 
The Court explained that Pickering balancing is to be preceded by a threshold test implicit in Pickering itself: if an employee's speech "cannot be fairly characterized as constituting speech on a matter of public concern, it is unnecessary for [the Court] to scrutinize the reasons for [the employee's] discharge."22 The Court proceeded to examine the questionnaire for matters of public concern, finding that only one of Myers's fourteen questions-regarding pressure to work on political campaigns-passed this threshold and merited Pickering balancing. In applying Pickering balancing to that question, the Court found that although Myers's ability to perform her own duties had not been impaired, ${ }^{23}$ her actions may have impaired the efficiency of the office. ${ }^{24}$

Connick, then, added to Pickering a "public concern" threshold test designed to distinguish speech that will be subjected to a balancing of interests from speech that will be treated as if the government were a private employer and not subject to First Amendment restrictions at all. As a threshold, it is intended to reduce the number of employment decisions generating constitutional challenges ${ }^{25}$ while preserving the First Amendment's protection of worthy public employee speech.

The only free speech case involving a public employee decided by the Supreme Court since Connick is Rankin v McPherson. ${ }^{28}$ McPherson was a clerical employee working in a constable's office. After hearing of an assassination attempt on President Reagan's life, McPherson remarked to a fellow employee, "If they go for him again, I hope they get him." A third worker overheard the remark and reported it to the constable, Rankin; Rankin called McPherson into his office and fired her when she confessed to the remark. The Rankin Court found that McPherson's remark "plainly dealt with a matter of public concern" because "[i]t came on the heels of a news bulletin regarding what is certainly a matter of heightened

${ }^{22}$ Id at 146.

${ }^{23}$ Id at 151.

${ }^{24}$ The Court explained that:

Here the questionnaire was prepared and distributed at the office; the manner of distribution required not only Myers to leave her work but others to do the same in order that the questionnaire be completed. Although some latitude in when official work is performed is to be allowed when professional employees are involved, and Myers did not violate announced office policy, the fact that Myers, unlike Pickering, exercised her rights to speech at the office supports Connick's fears that the functioning of his office was endangered.

Id at 153.

${ }^{25} \mathrm{Id}$ at 143.

${ }^{28} 483$ US 378, $107 \mathrm{~S} \mathrm{Ct} 2891$ (1987). 
public attention: an attempt on the life of the President."27 Having determined that McPherson's speech addressed a matter of public concern, the Court performed the requisite balancing and was "not persuaded that Rankin's interest in discharging [Myers] outweighed her rights under the First Amendment."28

The importance of Rankin lies in its extension of the Pickering/Connick regime beyond speech critical of the employer. In Pickering, the Court had purported to adopt a balancing test for "the enormous variety of fact situations in which critical statements by teachers and other public employees may be thought by their supervisors, against whom the statements are directed, to furnish grounds for dismissal." ${ }^{2 \theta}$ Connick claimed only to clarify the balancing test's threshold. Rankin, however, applied Pickering balancing and the Connick public concern threshold to speech unrelated to criticism of the employee's supervisor or ultimate employer. ${ }^{30}$ The result is that the Pickering/Connick test for deciding public employee free speech cases now applies to a broad spectrum of public employee speech.

\section{The Baby and the Bath Water: Free Speech Rights of} Public Employees Under the Public Concern Threshold Test

The Connick Court justified its adoption of a threshold test on the perceived need to keep frivolous claims from paralyzing the state's employment decisions. The Court cited the "common-sense realization that government offices could not function if every employment decision became a constitutional matter." ${ }^{31}$ Although the Connick Court's concern about Pickering's allocation of burdens is well-founded, it does not compel a threshold based on public concern. A threshold test could take many forms, and public concern is only one variation. The selection of a threshold test should depend not only on whether the test preserves judicial re-

${ }^{27}$ Id at $2897-98$.

28 Id at 2900 .

${ }^{29}$ Pickering, 391 US at 569 (emphasis added).

so Rankin was the first case to extend the application of Pickering in this way. See Perry, 408 US at 595 (Sindermann was not offered a contract renewal, allegedly because of his public criticism of a college administration); Mt. Healthy, 429 US at 282 (the release of an internal memo on the school's dress and appearance code for teachers was construed as "criticism" of the administration); Givhan, 439 US at 412-13 (Givhan criticized a School District's practices and policies, which she considered racially discriminatory); and Connick, 461 US at 141 (Myers distributed a questionnaire soliciting criticism of the district attorney from other assistant district attorneys).

31 Connick, 461 US at 143. 
sources-many threshold tests could accomplish that goal-but on whether the test properly selects cases in which the individual should be subject to the unique First Amendment balancing applied to public employees. The public concern threshold, however, defies the intuitions that inspired Pickering balancing.

\section{A. Precedential Basis of the "Public Concern" Test}

The Connick Court introduced the public concern threshold test as but another step in the "historical evolvement of the rights of public employees." 32 It cited, as prior steps in this evolution, a line of cases from the 1950s and 1960s (identified as "the precedent in which Pickering is rooted"), ${ }^{33}$ and three cases that the Supreme Court had decided since Pickering. ${ }^{34}$ Each of these cases, the Court observed, involved speech on matters of public concern. But the fact that these previous cases had involved speech of public concern was not reason, in itself, to limit constitutional protections to speech of public concern. The Court had rejected just this kind of inductive reasoning in a related case, when it brushed aside the argument that employee speech made privately should receive no constitutional protection just because all prior employee speech cases had involved speech made publicly. The Court wrote:

The Court's [precedents] do not support the conclusion that a public employee forfeits his protection against governmental abridgement of freedom of speech if he decides to express his views privately rather than publicly. While those cases each arose in the context of a public employee's public expression, the rule to be derived from them is not dependent on that largely coincidental fact..$^{35}$

In reality, neither the courts nor the parties in any of the cases cited in Connick had contended that the speech was not of public concern. The Supreme Court had simply not yet decided a case in which the significance of public concern was placed in issue.

${ }^{32}$ Id.

${ }^{33}$ Id at 144. See, for example, Wieman $v$ Updegraff, 344 US 183 (1952) (prohibiting the state from requiring employees to swear an oath denying past affiliation with Communists); Cafeteria Workers v McElroy, 367 US 886 (1961) (prohibiting the state from using previous membership in certain political parties as a basis for denying employment); and Keyishian $v$ Board of Regents, 385 US 589 (1967) (prohibiting the state from denying government employment to members of "subversive" organizations).

${ }^{34}$ See Perry, 408 US 593; Mt. Healthy, 429 US 274; and Givhan, 439 US 410. These cases are discussed in more detail in notes 20 and 30 .

${ }^{30}$ Givhan, 439 US at 414. 
The Connick Court's discovery of a threshold test implicit in Pickering is also misplaced. Under Pickering, "public concern" was merely one of several factors to be considered in the balancing of interests. ${ }^{36}$ Moreover, the burden of proof was assigned in Pickering such that a court would only consider "public concern" once the government had proved disruption..$^{37}$ If the government failed to show that a statement disrupted the workings of government, the speech would be protected..$^{38}$

Finally, the trend of the Court's decisions in the area was quite the opposite of what Connick suggested. Since the 1950s, the Court had steadily expanded the free speech rights of public employees. ${ }^{39}$ Connick constricted these rights by withdrawing protection from all speech not deemed of public concern. ${ }^{40}$

\section{B. The Many Faces of Public Concern in the Lower Courts}

Despite the fact that precedent does not compel the public concern threshold, the choice of "public concern" as the line between protected and unprotected speech is not arbitrarý. A major

${ }^{36}$ See Recent Decisions, Constitutional Law: Balancing Test Applied to Teacher's Criticism of School Board, 35 Brooklyn L Rev 270, 273-74 (1969).

${ }^{37}$ Pickering implicitly creates a three-part burden of proof scheme. First, the employee must prove a causal link between the employee's speech and the employer's retaliation (i.e., termination, failure to give a promotion, etc.). Second, if the employee meets this initial burden, the employer must show that the speech impeded the employee's performance or otherwise interfered with the efficient operations of government. If the employer meets that burden, the court balances the interests of the employer against the interests of the employee. See Note, The Nonpartisan Freedom of Expression of Public Employees, 76 Mich L Rev 365, 369-70 (1977).

38 See Note, Connick v. Myers: New Restrictions on the Free Speech Rights of Government Employees, 60 Ind L J 339, 354 (1985):

The [Pickering] Court's reasoning [ ] leads unmistakably to the conclusion that Pickering's status as a teacher at the high school would militate against his right to criticize the school administration only if his conduct impeded the operations of the school system. There is no suggestion in the Pickering opinion that a public employee who wishes to discuss a matter not of general interest must do so at his own risk. Denying a discharged public employee an opportunity to demonstrate that his speech affected neither his own performance nor the operations of the agency because his expression is not of public concern, as the Connick decision does, is a drastic and dangerous extension of the Pickering rationale.

39 For an excellent description of the expansion of free speech for public employees from Pickering to Connick, see Comment, The Public Employee's Right of Free Speech: A Proposal for a Fresh Start, 55 U Cin L Rev 449, 450-64 (1986).

${ }^{10}$ Prior to Connick, the Eighth and Ninth Circuits had assumed that public concern was a prerequisite to First Amendment protection. See Gieringer v Center School Dist. No. 58, 477 F2d 1164, 1167 (8th Cir 1973); and Bernasconi v Tempe Elementary School Dist. No. 3, 548 F2d 857, 861 (9th Cir 1977) (quoting district court opinion). Two circuit court opinions hardly constitutes a trend in Supreme Court jurisprudence, however. 
purpose of the First Amendment was to "protect the free discussion of governmental affairs." 41 The Connick Court, drawing on this tradition, used the concept of public concern to distinguish cases in which the courts would interfere with a public employment relationship from cases in which the courts would defer to the public employer's decision. So characterized, the public concern threshold can be supported: it provides limited First Amendment protection (in the form of Pickering balancing) to the most important forms of expression while allowing the state's efficiency interests to trump less important types of expression. Stated another way, the public concern test is designed to determine whether an employee's speech "takes on significance outside the workplace or whether it deals primarily with an employee's personal employment problem."42 Nevertheless, the test is problematic and vague, and unnecessarily abridges the free speech rights of public employees.

The most fundamental problem with the public concern threshold test has emerged from attempts to apply it: no one knows what "public concern" is. Connick defined "public concern" as "any matter of political, social, or other concern to the community"43 in light of "the content, form, and context of a given statement, as revealed by the whole record." 44 More specifically, the Court noted that "mere extensions of [a personnel] dispute"45 are not of public concern. On the other hand, the Court explained that public concern included statements: (1) "of public import in evaluating the performance of ... an elected official"; (2) "seek[ing] to inform the public that the [government office or agency] was not discharging its governmental responsibilities"; and (3) "seek[ing] to bring to light actual or potential wrongdoing or breach of the public trust on the part of [a government official]."46

These descriptions of public concern provided just enough guidance to confuse everyone. As Justice Brennan predicted in his Connick dissent, ${ }^{47}$ the concept eluded consistent definition as the

41 Mills v Alabama, 384 US 214, 218 (1966).

42 Flanagan v Munger, 890 F2d 1557, 1564 (10th Cir 1989).

43 Connick, 461 US at 146.

4 Id at 147-48.

45 Id at 148.

16 Id.

47 Justice Brennan wrote:

The Court recognized the sensitive nature of [determining public concern] in Gertz $v$. Robert Welch, Inc., 418 U.S. 323 (1974), which held that the scope of the constitutional privilege in defamation cases turns on whether or not the plaintiff is a public figure, not on whether the statements at issue address a subject of public concern. In so doing, 
lower courts developed their own "public concern" jurisprudence. Many circuit courts condition their protection of public employee speech on whether the speech will help the public evaluate the performance of government. ${ }^{48}$ This narrow conception of the threshold test, however, excludes from First Amendment protection artistic, commercial, and other speech that is normally protected. Moreover, this approach merely replaces the indeterminate "public concern" with the indeterminate "useful."

Other courts have focused on the speaker's intent. The Seventh Circuit has reasoned that the Connick test "requires us to look at the point of the speech in question: was it the employee's point ... to raise other issues of public concern because they are of public concern ... [ [or] to further some purely private interest?"49 But focusing on the speaker's intent fails to protect speech in which an employee inadvertently touches on a matter of public concern or purposefully avoids making the speech public out of concern for the person criticized..$^{50}$

the Court referred to the "difficulty of forcing state and federal judges to decide on an ad hoc basis which publications address issues of 'general or public interest' and which do not," and expressed "doubt [about] the wisdom of committing this task to the conscience of the judges."

Id at 164 (Brennan dissenting).

18 See, for example, McKinley $v$ City of Eloy, 705 F2d 1110, 1114 (9th Cir 1983). This standard has its roots in Connick's observation that courts should consider whether statements "are of public import in evaluating the performance of ... an elected official." 461 US at 148. That language is too narrow, however, because many public employee cases involve behavior by an unelected official.

The Tenth Circuit has distinguished the subject matter of the speech from the actual content of the speech. In Koch $v$ City of Hutchinson, for example, a fire marshall's report on a fire that killed a small child was held not to be of public concern, even though the investigation of the fire itself was "a matter of great public concern." Since the report was a routine part of the marshall's duties, it did not "sufficiently inform the issue as to be helpful to the public in evaluating the conduct of government." 847 F2d 1436, 1447 (10th Cir 1987) (citations omitted).

The Eleventh Circuit has also emphasized the usefulness of the speech to the public. In Ferrara v Mills, 781 F2d 1508, 1514 (11th Cir 1986), the court followed Justice Brennan's admonition that " $[t]$ he First Amendment affords special protection to speech that may inform public debate about how our society is to be governed-regardless of whether it actually becomes the subject of a public controversy." (emphasis in original) (quoting Connick, 461 US at 160 (Brennan dissenting)).

40 Linhart $v$ Glatfelter, 771 F2d 1004, 1010 (7th Cir 1985). Along with the Seventh Circuit, other circuits that have examined motive to determine public concern include the Fifth Circuit (Gomez v Texas Dept. of Mental Health, 794 F2d 1018, 1022 (5th Cir 1986)); the Tenth Circuit (Koch $v$ City of Hutchinson, 847 F2d 1436, 1445-46 (10th Cir 1987)); and the Eleventh Circuit (Morales v Stierheim, 848 F2d 1145, 1149 (11th Cir 1988)).

so See, for example, Callaway v Hafeman, 832 F2d 414 (7th Cir 1987). Franzetta Callaway, a school district employee, complained of sexual harassment by her supervisor. The supervisor later gave Callaway a negative performance evaluation, after which Callaway was 
In determining whether speech is of public concern, the Eighth Circuit has inquired whether actual public debate occurred on the matter. ${ }^{51}$ This standard, however, does not adequately protect two types of speech expressly provided for in Connick: speech "seek[ing] to inform the public that the [government office or agency] was not discharging its governmental responsibilities," and speech "seek[ing] to bring to light actual or potential wrongdoing or breach of the public trust on the part of [a government official]." "63 There is a certain perversity in permitting the state to punish an employee who attempts to disclose wrongdoing merely because that wrongdoing has not yet been publicly debated.

The Fifth Circuit has attempted to divine matters of public concern through standards applied to the "the content, form, and context of a given statement."." The result is a laundry list of relevant considerations: (1) whether the communication relates to the policies of the institution or to the actions of other employees; ${ }^{55}(2)$ whether the communication is in-house; ${ }^{56}$ (3) whether the em-

transferred to a position that was considered a demotion. The Court held that Callaway's speech was not protected under the intent inquiry:

Prior to the commencement of this litigation, Callaway limited her complaints of sexual harassment to oral statements intended to be purely confidential. As Callaway explained in a meeting with several of the defendants, she wanted her grievance to be resolved internally to avoid a public controversy.... While the content of Callaway's communications touched upon an issue of public concern generally, she was not attempting to speak out as a citizen concerned with problems facing the school district; instead, she spoke as an employee attempting to resolve her private dilemma.

Id at 417.

The Callaway case shows that an employee who conscientiously attempts to resolve a dispute within the office may not be protected. Had Callaway gone to the public, possibly an irresponsible and rash act, she would have been rewarded with First Amendment protection. The creation of such perverse incentives probably outweighs any gains in determinacy that the intent inquiry might achieve.

${ }^{32}$ See Lewis v Harrison School Dist. No. 1, 805 F2d 310 (8th Cir 1986); and Patteson v Johnson, 721 F2d 228, 233 (8th Cir 1983). The Eight Circuit has considered other factors besides "actual public debate," however. See Southside Pub. Schools v Hill, 827 F2d 270, 273 (8th $\mathrm{Cir}$ 1987) (inquiring whether the grievance related merely to a private employment matter or personal vendetta); and Hamer $v$ Brown, 831 F2d 1398, 1402 (8th Cir 1987) (citing Connick and holding that speech was of public concern because it related to a matter of "political, social, or other concern to the community.").

${ }^{52}$ Connick, 461 US at 148.

${ }^{53}$ Id.

s4 Id at $147-48$.

${ }^{5 s}$ See Davis $v$ West Community Hospital, 755 F2d 455, 461 (5th Cir 1985) (A person speaks as an employee when the speech relates solely to the person's employment. Statements are not of public concern, therefore, if they do "not involve any policy or practice of the [government agency]; and they are related only to isolated, unsubstantiated acts by specific individuals.").

${ }^{s 8}$ See id ("The fact ... that the communications here were inhouse does not necessa- 
ployee is a policy maker; ${ }^{57}$ (4) whether the employee tries to communicate to the public; ${ }^{68}$ and (5) whether people outside the workplace debate the subject of the speech. ${ }^{58}$

The Supreme Court had an opportunity to resolve the confusion among the circuits and clarify the definition of "public concern" in Rankin $v$ McPherson. ${ }^{60}$ The Court, however, merely asserted that McPherson's comment to her co-worker "plainly dealt with a matter of public concern" because "[i]t came on the heels of a news bulletin regarding what is certainly a matter of heightened public attention: an attempt on the life of the President." ${ }^{61}$ Contrary to the Court's suggestion, "heightened public attention" should not determine whether speech deserves First Amendment protection. In a case that preceded Rankin, the Seventh Circuit argued convincingly that "public interest" is not that same as "public concern":

In assessing whether the speech touches upon a matter of public concern, it is important not to equate the public's curiosity about a matter with a matter having societal ramifications. People may be interested in any number of aspects of the lives of public officials and employees, but that does not mean that such matters have societal ramifications. Conversely, the public may be apathetic about certain matters of public concern, but the unpopularity of the issue surely does not mean that a voice crying out in the wilderness is entitled to less protection than a voice with a large receptive audience. ${ }^{62}$

rily destroy their protection under the First Amendment, but it is part of the context of the communication to be considered in determining whether the speech addressed a matter of public concern.").

s7 See Gonzales $v$ Benavides, 774 F2d 1295, 1300 (5th Cir 1985) ("senior government employees who exercise broad discretionary authority may be able to 'make or break' the programs and policies of elected officials," so they should not be allowed to speak as freely as those who do not make policy).

ss See Gomez v Texas Dept. of Mental Health, 794 F2d 1018, 1022 (5th Cir 1986) (because an employee "was not seeking to alert the public to any actual or potential wrongdoing or breach of the public trust by the administrators of the State Center," his communication was not a matter of public concern).

so See id at 1021.

so 483 US 378, 107 S Ct 2891 (1987).

$6107 \mathrm{~S} \mathrm{Ct}$ at 2898 (footnote omitted).

62 Egger v Phillips, 710 F2d 292, 316-17 (7th Cir 1983). 
Like the Seventh Circuit, the Rankin dissent ${ }^{63}$ and some commentators $^{64}$ have questioned Rankin's use of "public interest."

The great differences among the circuits and the failure of the Supreme Court to define "public concern" is problematic. Rather than mitigating the harms of indeterminacy resulting from Pickering balancing, the public concern threshold only adds to the indeterminacy.

\section{Speech Unrelated to Employment}

Even if an adequate definition of "public concern" could be derived, the public concern threshold should be abandoned because it denies the full protection of the First Amendment to public employees when their speech is unrelated to the employment. The Fourth Circuit uncovered this shortcoming in Berger $v$ Battaglia. ${ }^{66}$ Berger, a Baltimore police officer, performed in blackface during his off-duty hours. He never identified himself as a policeman, but the entertainment press sometimes did. When an advertisement for a show raised protests from the black community, the police department ordered Berger to stop performing. Berger sued to challenge the order. The circuit court distinguished this case, involving a policeman's artistic expression, from the "paradigmatic Pickering pattern" because "the employee speech was not criticism of or disagreement with governmental operations, and the governmental interest assertedly threatened by the speech was not internal employment relationships and operations."

Although the officer's artistic expression was far removed from his employment, Connick would allow the employer to restrict the speech because it was not "on a matter of public concern."

63 Rankin, $107 \mathrm{~S} \mathrm{Ct}$ at 2904 (Scalia dissenting).

64 See, for example, Note, Rankin v. McPherson: The Court Handcuffs Public Employers, 19 Pac L J 1543, 1560 (1988).

65 The Sixth Circuit's analysis of "public concern," however, seems very close to a "public interest" standard. In Rowland v Mad River Local School Dist., 730 F2d 444 (6th Cir 1984), a public schoolteacher was fired after admitting that she was a bisexual. To show that the speech was of interest only to Rowland, the court stated that no evidence had been presented showing that the community was concerned with the bisexuality of school personnel and that Rowland had attempted to keep the communications confidential. Id at 449.

68 779 F2d 992 (4th Cir 1985).

67 Id at 997.

68 The definition of public concern given in Connick seems broad: "relating to any matter of political, social, or other concern to the community." Connick 461 US at 146. As applied in Connick, however, the definition was very narrow. As discussed at note 24, only one of the questions asked by Myers-whether the assistant district attorneys faced official political pressure-was deemed "of public concern." Id at 149. Questions dealing with the district attorney's transfer policy, the confidence of workers in superiors, employee griev- 
avoid this incongruous result, the Fourth Circuit turned Connick on its head:

[T] he "public concern" or "community interest" inquiry is better designed-and more concerned-to identify a narrow spectrum of employee speech that is not entitled even to qualified protection than it is to set outer limits on all that is. The principle that emerges is that all public employee speech that by content is within the general protection of the first amendment is entitled to at least qualified protection against public employer chilling action except that which, realistically viewed, is of purely "personal concern" to the employee-most typically, a private, personnel grievance. ${ }^{69}$

This interpretation suggests that Connick's formulation of the public concern threshold requirement allows the state to limit speech normally protected by the First Amendment, even when the speech is only distantly connected with the employment. ${ }^{70}$ In other words, the public concern threshold ensures that the public employee will never have the full protection of the First Amendment.

In Flanagan $v$ Munger, ${ }^{71}$ a case "analytically indistinguishable" from Berger, the Tenth Circuit dismissed the public concern threshold as "irrelevant" to public employee speech made "off the job and unrelated to any internal functioning of the department."72 In Munger, several Colorado Springs police officers were part owners of a video store that rented sexually explicit-but not legally "obscene"-films. After receiving an anonymous complaint, the police chief asked the officers to remove the films from their store (they did) and informed them that he would issue a reprimand for violating department regulations. ${ }^{73}$

The circuit court held that the public concern threshold only applies to speech made "at work or related to work." Where, as in this case, the speech was made away from the workplace on a subject unrelated to the employment, the court found it "nearly

ance procedures, and office morale were not of public concern.

69 Berger, $779 \mathrm{~F} 2 \mathrm{~d}$ at 998 (emphasis in original) (citations omitted).

${ }^{70}$ But the Berger court's solution is largely ineffectual, because it substitutes a notion of "personal concern" for the notion of "public concern." It seems unlikely that "personal concern" will be any easier to determine than "public concern."

${ }^{71} 890$ F2d 1557 (10th Cir 1989).

72 Id at 1564-65.

${ }^{73}$ Id at $1560-61$.

74 Id at 1562. 
impossible to logically apply the public concern test." to the Munger court, the test was not intended to apply to speech unrelated to the employment, where the person is not speaking as an employee. ${ }^{76}$

Up to this point, the Munger court was undoubtedly correct. Connick was never intended to apply to such speech, ${ }^{77}$ but Rankin's extension of Connick shows that application of the public concern test in the Berger/Munger context is plausible. The Munger court, however, created a troublesome new threshold for speech "unrelated" to employment-whether the speech was "protected expression." "78 According to the court, if the speech were protected expression, as in Munger itself, then it should be subjected to Pickering balancing. In Munger, the police officers prevailed under the balancing because their speech had not disrupted the efficiency of the police department. ${ }^{79}$ Had their speech been "unprotected expression," the reprimands would have been upheld. Munger perpetuates the fraws of Connick and Berger: unlike Pickering, it provides public employees only qualified First Amendment protection in the form of balancing, even when their speech is unrelated to their employment.

\section{The Proposed Threshold Test}

The Supreme Court has correctly determined that speech by public employees should be subjected to a unique First Amendment standard because public employees are in a unique position to impair government operations. In Munger, the Tenth Circuit attempted to overcome the difficulties of the current Pickering/Connick test, but, as this Comment suggests, it did not solve all the problems. To address these concerns, this Comment proposes a new threshold test for First Amendment analysis of public employee speech.

75 Id.

${ }^{76}$ Id at 1564.

${ }^{77}$ Dissenting in Connick, Justice Brennan assumed that the public concern threshold did not apply to speech like that in Berger and Munger: "When public employees engage in expression unrelated to their employment while away from the workplace, their First Amendment rights are, of course, no different than those of the general public." Connick, 461 US at 157 (Brennan dissenting).

${ }^{78}$ Munger, $890 \mathrm{~F} 2 \mathrm{~d}$ at 1564.

${ }^{78}$ Id at 1565. 


\section{A. Burdens of Proof}

Before introducing the new threshold test, it is necessary to consider the preliminary matter of the assignment of burdens of proof. When a public employee raises a First Amendment challenge to an employment decision, the employee has traditionally borne and should bear the burden of proving causation (i.e., "the employer fired me because of my speech"). ${ }^{80}$ This burden is not excessive: to allow an employee to prevail without proving grounds for recovery would encourage employees to bring baseless suits in the hope that the government would fail to sustain its burden of proof.

Requiring proof of causation ensures that the employer acted in response to the employee's speech. The state may contest causation, arguing that the speech did not precipitate the sanction. ${ }^{81}$ An employer may have many reasons for terminating or disciplining an employee, and the employee can sustain a First Amendment claim only if the employer acted primarily to suppress the employee's speech. This standard prevents employees who were about to be fired from avoiding legitimate employment-related discipline by engaging in protected speech. ${ }^{82}$

In addition to proof of causation, the Court has required the employee to demonstrate that his conduct was constitutionally protected. ${ }^{83}$ In most cases, this burden would require little more than proof of what was said. But in some First Amendment contexts, it could create odd allocations of proof. For example, must an employee accused of libelous speech prove the truth of the speech or absence of malice? If so, then the normal First Amendment burdens would be inverted, because the government official is normally required to show falsity or malice. A better solution

so This situation might be analogized to race and gender discrimination cases, where the plaintiff must show that the state action was directed at the plaintiff's race or gender. In the context of Title VII, see McDonnell Douglas Corp. v Green, 411 US 792, 802 (1973); and Texas Dept. of Community Affairs v Burdine, 450 US 248 (1981).

s1 See Mt. Healthy, 429 US at 287; Caffas $v$ Bd. of School Directors, $23 \mathrm{~Pa}$ Commw 578, 353 A2d 898, 899 (1976) (teacher dismissed because of cruelty to students, not because speech was critical of the school's administration).

B2 See Mt. Healthy, 429 US at 286:

A borderline or marginal candidate should not have the employment question resolved against him because of constitutionally protected conduct. But that same candidate ought not to be able, by engaging in such conduct, to prevent his employer from assessing his performance record and reaching a decision not to rehire on the basis of that record, simply because the protected conduct makes the employer more certain of the correctness of his decision.

ss Id at 287. 
would allow "unprotectedness" as a justification for government action. The government could justifiably fire or discipline an employee because the employee engaged in speech that would not merit First Amendment protection, even if made by an ordinary citizen. The Court in Pickering, for example, would have denied the teacher's First Amendment claim had his speech been libelous. But, as in Pickering, the government should have the burden of proving that the speech would ordinarily lack protection. ${ }^{84}$

\section{B. The Proposed Threshold Test}

The premise of this proposed threshold test is that before an individual's speech is subjected to the balancing of interests for public employees, the speech should be sufficiently related to the employment so that the individual can be said to be speaking as a public employee rather than as an ordinary citizen. The proposed threshold test is:

Public employee speech is immune from employment-based sanctions by the state if it: (1) is made away from the workplace; and (2) concerns matters unrelated to workplace personnel or policies or unrelated to political issues directly affecting the employee's working relationships.

The key concept in the proposed test is "relatedness": if speech is sufficiently related to the employment, the individual speaks as an employee; otherwise, the individual speaks as a citizen. The sufficiency of the relation between the speech and employment is measured by two criteria: location and content. These two criteria reflect the underlying rationale for the proposed threshold: namely, that an individual who becomes a public employee does not forfeit the constitutional rights he would otherwise exercise as a citizen, but that those rights may be altered by the existence of the employment relationship. The proposed threshold suggests, therefore, that the effect of the employment relationship extends only to speech which is "related" by location or content to the employment.

Pickering assumes that if an employee's speech disrupts government efficiency, the employment relationship justifies stricterthan-usual First Amendment standards (i.e., a balancing of interests); if speech does not disrupt government efficiency, the employ-

\footnotetext{
84 The Court held that Pickering's speech should be protected "absent proof of false statements knowingly or recklessly made." Pickering, 391 US at 574. The implication is that the government employer would have the burden of proof.
} 
ment relationship is irrelevant and the employee's speech is subject to the same First Amendment standards as speech by an ordinary citizen. ${ }^{85}$ But Pickering's effects-based test was itself problematic: because employees could not confidently predict the effects of their speech, they did not know in advance whether their speech would be protected by ordinary First Amendment standards or the more restrictive balancing of interests..$^{86} \mathrm{~A}$ primary advantage of the proposed threshold test is its "reckonability." It allows employees to evaluate ex ante whether their speech is protected by broad or narrow First Amendment standards.

Although this Comment accepts Pickering's notion that public employees may be subjected to stricter standards than ordinary citizens because of their potential for disruption, it argues that disruption need not be considered at this threshold stage. By considering disruption, Pickering ensured that only disruptive speech would be subjected to the restrictive balancing of interests. That goal is also achieved under the proposed formulation because the employer must prove the existence of disruption under the balancing of interests, discussed in the following section, in order to restrict the employee's speech. Nondisruptive speech, therefore, will be protected whether it is immunized by a threshold test or by the balancing of interests itself.

The proposed threshold accepts the fact that speech made away from the workplace on subjects unrelated to employment may be disruptive. If, for example, an off-duty police officer. marches in an anti-abortion rally, some of the officer's coworkers and members of the community might be disturbed by the officer's expression, and their reaction could disrupt government operations. But the speech should be protected despite the disruption. The goal of the threshold determination is to select cases in which the relationship of the speech to the employment is so attenuated that a court could not justly apply the restrictive balancing of interests even though the speech ultimately disrupts government efficiency.

The proposed threshold steers a middle course between two extremes: the traditional right/privilege distinction and ordinary First Amendment standards. The right/privilege distinction allows an employee's First Amendment rights to be wholly abridged at the discretion of the employer. ${ }^{87}$ Ordinary First Amendment stan-

ss Pickering, 391 US at 569-73.

so See Recent Decisions, 35 Brooklyn L Rev at 275 (cited in note 36).

87 See text and notes $7,10$. 
dards allow abridgment only in exceptional cases. The proposed threshold permits the application of a more restrictive First Amendment standard (i.e., the balancing of interests), but only when the speech is related to the employment.

When speech is unrelated to the employment, therefore, courts should grant public employees a "safe harbor" from the restrictive First Amendment standards governing their employmentrelated speech. If the court determines that an individual has spoken as an employee, the court should apply the unique First Amendment standards for employee speech discussed in the following section. If the individual speaks as a citizen, the court should rule in favor of the public employee because the employee has already proven causation and the government has failed to prove unprotectedness.

The proposed threshold test immunizes a narrow range of public employee free speech cases. Pickering is such a case. ${ }^{\mathbf{8 8}}$ Under the proposed test, the teacher would have been absolutely protected from employment-based sanctions because his speech did not violate First Amendment libel standards (i.e., it was protected speech under the initial burden of proof) and he spoke (1) away from the workplace (in a letter to the local newspaper) and (2) on a matter not directly affecting his working relationships (the school board's handling of revenue proposals and its allocation of funds).

\section{Beyond the Threshold: The Free Speech Rights of Public Employees}

Any attempt by the state to restrict employment-related speech creates a tension between the interests of the employee in speaking freely and the interests of the government in operating efficiently. The Supreme Court has chosen to resolve that tension by balancing the interests in "public concern cases" on a case-bycase basis. In a world with perfect information and perfect information processors, this balancing test would be ideal. The courts would decide each case correctly because they could assess the precise weight of the competing interests. But we do not live in that world, and any time a court is asked to assign "weights" or "values" to .abstract notions like "disruption" and "free speech," the

\footnotetext{
${ }^{88}$ Other cases that would be immunized by the proposed threshold include Berger $v$ Battaglia, 779 F2d 992 (4th Cir 1985), discussed in text at notes 66-70; and Flanagan v Munger, 890 F2d 1557 (10th Cir 1989), discussed in text at notes 71-79.
} 
outcome will be indeterminate and the expenditure of judicial resources high.

This Comment proposes evaluating the free speech rights of public employees not by balancing the competing interests once a case has arisen, but by applying two objective inquiries that themselves capture the relevant individual and public values. First, the court should ask: Can the state prove that the employee's speech actually caused disruption of government efficiency? If it cannot, it may not sanction the employee. If the state can prove actual disruption, then it may sanction the employee unless the employee can demonstrate that the speech was more valuable to the public than the disruption it caused. This value is proved not by entering evidence of the cost of the disruption and the value of the speech, but by answering the court's second question: Does the speech "bring to light actual or potential wrongdoing or breach of public trust on the part of [a government official]"?

This proposed analysis accounts for the interests of both the state and the individual. The individual's interest in engaging in speech unrelated to employment is preserved by the new, twopronged threshold test discussed in section III. In addition, the individual may engage in unlimited non disruptive employment-related speech, but faces the threat of employment-related sanctions if he engages in disruptive, employment-related speech.

Finally, the proposed test permits a government employee to engage in disruptive, employment-related speech that reveals wrongdoing or a breach of public trust. The state undoubtedly has an interest in restricting disruptive speech in order to promote the efficient and effective provision of government services, but when disruption is the result of an employee revealing wrongdoing or a breach of public trust, the state's interest in restricting such speech ceases. Its interest in the efficient and effective provision of government services is furthered when wrongdoing and breaches of public trust are prevented or corrected.

\section{A. Employer Proves Disruption}

Pickering would have required employers attempting to justify their discharge or discipline of an employee to prove that the employee's speech was actually disruptive. But actual disruption is

8o Connick, 461 US at 148. Connick used this formulation as one of its definitions of "public concern." Although the concept of "public concern" is generally troublesome, this particular aspect is quite useful. 
very difficult to prove. Perhaps to lighten the burden of proof, the Connick Court accorded the employer, District Attorney Connick, a great deal of deference. Although the lower courts had found no proof that Myer's questionnaire caused any actual disruption, Connick testified that working relationships had been disturbed. The Court concluded:

When close working relationships are essential to fulfilling public responsibilities, a wide degree of deference to the employer's judgment is appropriate. Furthermore, we do not see the necessity for an employer to allow events to unfold to the extent that the disruption of the office and the destruction of working relationships is manifest before taking action. We caution that a stronger showing may be necessary if the employee's speech more substantially involved matters of public concern. ${ }^{90}$

The dissent in Connick objected to the majority's deference to the employer's judgment and stated that the majority had "misapplie[d] the Pickering test." The dissent pointed out that the majority had contradicted "previous authorities" by holding "that a public employer's mere apprehension that speech will be disruptive justifies suppression of that speech when all the objective evidence suggests that these fears are essentially unfounded."

As the dissent correctly stated, Pickering implicitly required a showing of actual harm. The Pickering Court noted: "[The statements] are neither shown nor can be presumed to have in any way either impeded the teacher's proper performance of his daily duties in the classroom or to have interfered with the regular operation of the schools generally." ${ }^{\text {"92 }}$ Many of Pickering's progeny required the employer to show actual harm. ${ }^{93}$

It makes sense to place the burden of proof on the employer once the employee has shown causation. Imagine a case where neither the employer nor the employee can carry an initial burden

${ }^{80}$ Connick, 461 US at 151-52 (emphasis added) (footnote omitted).

${ }^{21}$ Id at 166 (Brennan dissenting).

${ }^{92} 391$ US at 572-73 (footnote omitted).

${ }^{93}$ See Tygrett $v$ Washington, 543 F2d 840, 848 (DC Cir 1974) ("The crucial question for decision was whether appellant's remarks, in the particular circumstances surrounding them, actually impinged upon qualities making for an effective police force in such a manner as to imperil its efficiency.") (emphasis added) (footnote omitted); and James $v$ Bd. of Education, 461 F2d 566, 571 (2d Cir 1972) ("Any limitation on the exercise of constitutional rights can be justified only by a conclusion, based on reasonable inferences flowing from concrete facts and not abstractions, that the interests of discipline or sound education are materially and substantially jeopardized ...."). 
of proof (i.e., the employer can't show disruption and the employee can't show public value). In this case, the public employee should prevail because public employers should be required to justify employment-related sanctions that serve to restrict free speech. The employer, therefore, should have the initial burden of proof. But the burden of proving actual disruption is onerous, at least in part because of the indeterminacy of "disruption." That burden can be lightened by objectifying the test for disruption.

Objective criteria for disruption can be found in Pickering itself. The Court listed four "general lines along which an analysis of the controlling interests should run."94 Of the four, three dealt with the disruptive effect of the speech on the efficiency of the government: (1) whether the statements were directed at any person with whom the appellant would normally be in contact in the course of daily work; 95 (2) whether the speaker or the speaker's coworkers were unable to perform their daily duties or whether the agency was unable to maintain regular operations; ${ }^{96}$ and (3) whether the harmful impact of the speech on the public would be difficult for the government to counter. ${ }^{97}$ Under the proposed analysis, if the employer can show that the speech at issue fits any one of the three criteria, the speech should be presumed to be disruptive.

1. Were the statements directed at any person with whom the appellant would normally be in contact in the course of daily work?

Although it may appear harsh to deem disruptive any speech "directed at" people with whom an employee would normally be in contact, the criterion implicitly requires that the speech actually concern the other person. In Rankin, therefore, an employee's statement about President Reagan was not "directed at" either coworker who heard the statement because the speaker was not criticizing the coworkers. Nevertheless, many types of speech typically engaged in by public employees would satisfy the "directed at" requirement. In Givhan $v$ Western Line Consolidated School District, for example, a school teacher confronted the principal with "criticism of the policies and practices of the school district, espe-

\footnotetext{
94 391 US at 569.

os Id at 569-70.

96 Id at 572-73.

${ }^{\circ 7}$ Id at 572.
} 
cially the school to which she was assigned to teach." ${ }^{98}$ Such speech would be considered disruptive under the proposed test because it concerned (was "directed at") the principal. ${ }^{9}$

This criterion is especially apt to identify employee criticism of a supervisor as disruptive. The Pickering Court was concerned about the employer's ability to maintain discipline and harmony in the workplace. By adversely affecting close working relationships, speech may lead to less efficient government. The effect of speech on close working relationships might also impair government services where "personal loyalty and confidence are necessary to their proper functioning." 100 The Court also hypothesized that other situations may involve the "need for confidentiality" or "personal and intimate" relationships to a degree that would justify government restrictions on speech, even if the speech is true. ${ }^{101}$

2. Were the speaker or his coworkers unable to perform their daily duties, or was the agency unable to maintain regular operations?

This criterion addresses speech that directly affects the workplace. In Connick, for example,

the questionnaire was prepared and distributed at the office; the manner of distribution required not only Myers to leave hèr work but others to do the same in order that the questionnaire be completed. Although some latitude in when official work is performed is to be allowed when professional employees are involved, and Myers did not violate announced office policy, the fact that Myers, unlike Pickering, exercised her rights to speech at the office supports Connick's fears that the functioning of his office was endangered. ${ }^{102}$

The disruption in Connick seemed rather minimal, but it was disruption nonetheless. At this point in the inquiry, a court is not establishing the limits of First Amendment protection. Rather, it is discerning potential grounds for governmental concern. Although

88 439 US 410, 413 (1979) (quoting the district court).

93 Although the value of this speech may be high, it cannot be denied that such speech is disruptive to working relationships, and at this stage of the analysis, disruption is all that is at issue. The speech in Givhan would ultimately be protected under the proposed analysis because the value of the speech (measured by the fact that it reveals a breach of public trust) outweighs the disruption that the speech causes.

100 Pickering, 391 US at 570.

101 Id at $570 \mathrm{n} 3$.

${ }^{102}$ Connick, 461 US at 153 (footnotes omitted). 
an employer may not be entirely reasonable in dismissing an employee for minor disruptions, the Court has never held that the First Amendment protects public employees from unreasonable employment decisions per se. The employee is only protected when his interest in speaking outweighs the government's interest in restricting speech.

3. Would it be difficult for the government to counter the harmful impact of the speech on the public?

This criterion deals with the efficiency concerns of government (albeit less obviously), because most, if not all, government agencies require public support to fulfill their functions. If an employee's speech injures the public's perception of the agency, the agency may be unable to provide its services efficiently. The ideal remedy for harmful public speech is counterspeech: the harm to the government can be eliminated if the government's view of the matter could be easily disseminated.

But, where counterspeech is unavailable, the agency's interests might be irreparably injured. In Allen $v$ Scribner, for example, a local supervisor on a larvae detection project told the media that the project's management "did not have a 'handle" " on the infestation of Mediterranean fruit flies. ${ }^{103}$ Such speech might be difficult to counter in the media, and if it is, the project would lose public support. In short, the speech would be disruptive.

The three objective criteria listed above represent the full "efficiency" interests of a government employer; the employer has no interest in restricting speech that does not meet one of these three broad criteria, and thus every employer must prove that the case fits within one of the criteria to justify a claim of disruption. In Pickering, the school board was unable to show that the letter fulfilled any of the criteria, and so the employee prevailed. In Connick, the employer showed that the speech was directed at him and that the speech prevented both the employee and her coworkers from performing their daily duties. ${ }^{104}$

103812 F2d 426, 428 (9th Cir 1987).

104 The Court in Connick seemed to rely more on the employer's fear of disruption than on actual disruption, finding that "there is no demonstration here that the questionnaire impeded Myer's ability to perform her responsibilities." 461 US at 151. But the quotation above (see text at note 102) indicates that some disruption took place. Under the objective criteria, therefore, the employer would be justified in acting. 
Finally, the constable in Rankin would not be able to show disruption under any of these criteria:

The Constable was evidently not afraid that McPherson had disturbed or interrupted other employees-he did not inquire to whom the respondent had made the remark and testified that he "was not concerned who she had made it to ..." In fact, Constable Rankin testified that the possibility of interference with the functions of the Constable's office had not been a consideration .... ${ }^{105}$

Although one might argue that the statement in Rankin prevented the coworker from accomplishing his daily duties, that was not the basis for McPherson's termination. Moreover, the coworker had to eavesdrop on a private conversation just to hear McPherson's speech. It was the coworker's own actions that prevented him from accomplishing his daily duties. A better argument would be that the speech took McPherson away from her own work. If this had been the basis for the termination, the government would have prevailed under the proposed analysis. Although employers often allow private conversations during working hours, the First Amendment should not require them to. An employee who detracts from work by engaging in personal conversations, therefore, does so at his own risk. In this situation, the employer fires the employee not because the employer was trying to suppress speech but because the employee was not doing his job.

The criteria for disruption are reasonable and prudent. They are reasonable because speech that fits any of the three criteria will almost always have an actual disruptive effect, even if the effect is small or difficult to prove empirically. The criteria are prudent because the presumptions prevent the burden of proving "disruption" from falling too heavily on the employer.

\section{B. Employee Proves Value of Speech}

According to Pickering and its progeny, disruptive speech merits First Amendment protection from employment-based sanctions only if its value exceeds the cost of the disruption it causes. As with the cost of disruption, the actual value of speech is impossible to determine. The next best solution, therefore, is an objective rule that approximates the expected balance of interests. An objective rule carries the additional advantages of providing em-

${ }^{205}$ Rankin, $107 \mathrm{~S} \mathrm{Ct}$ at 2899 (emphasis in original). 
ployees well-defined limits to their free speech rights and enabling courts to decide cases more easily and quickly. The proposed standard for deciding whether the speech's value exceeds the cost of disruption is simple: Does the speech "bring to light actual or potential wrongdoing or breach of the public trust on the part of [a government official]"? ${ }^{106}$

This inquiry is rooted in the dual roles that the individual and the state play in the public employment area. It has already been shown how the proposed threshold test provides protection for the public employee speaking as a citizen about matters unrelated to the employment. The proposed objective measurement of the value of a public employee's speech is designed to parallel and protect the public employee's interest in speaking as a citizen about workrelated matters.

Given the government's interest in the efficient provision of services, there is little employment-related, disruptive speech that should, as a policy matter, be protected from the control of the government as employer. By requiring that speech "bring to light actual or potential wrongdoing or breach of the public trust" before overriding proof of disruption, the proposed standard protects important employee speech without compromising government interests. The proposed standard addresses the real concern, indeed the essential justification for giving First Amendment protection to public employees at all; namely, attempts by the state, acting as employer, to suppress public employees from speaking as citizeins.

When an employee reveals wrongdoing or a breach of public trust, disruption is inevitable. The speech will often be directed at the employer, and will, by definition, be impossible for the employer to counter. But public employees are precisely "the members of the community most likely to have informed and definite opinions"107 about government corruption and ineptitude. If the employee can prove, therefore, that the speech reveals wrongdoing or a breach of public trust, the speech should be protected by the First Amendment.

This objective measurement of value does not depend on whether the speech actually reaches the public. Justice Brennan, in his dissent in Connick, observed that "[t]he First Amendment affords special protection to speech that may inform public debate about how our society is to be governed-regardless of whether it 
actually becomes the subject of a public controversy." 108 Thus, when an employee speaks on a matter that involves a breach of public trust, his speech should be protected, even if the speech never actually reaches the public.

\section{CoNCLUSION}

When the Supreme Court devised Pickering balancing, it did not "deem it either appropriate or feasible to attempt to lay down a general standard against which all [statements by public employees] may be judged."109 As the Court encountered more cases involving the free speech rights of public employees, it became more comfortable with the notion of general standards and adopted the public concern threshold test. The experience of the courts reveals that the public concern threshold is an indeterminate and unjust First Amendment standard for public employee speech. This Comment proposes a change.

The change features a new threshold test that characterizes speech based on its relationship to employment. If a public employee's speech is "unrelated" to his employment, the speech should be evaluated under the same First Amendment standards applicable to similar speech made by ordinary citizens. Conversely, if the employee's speech is "related" to his employment, the speech should be evaluated under First Amendment standards that protect the government's interest in providing its services efficiently. Currently those standards are embodied in Pickering's balancing of interests, but this Comment proposes objective rules that approximate the results of balancing without the indeterminacy and excessive expenditure of judicial resources inherent in balancing.

The risk of framing objective rules such as those proposed here is that cases may push the limits of those rules, making them seem unfair or nonsensical. One of the costs of determinacy is that cases will not always receive the tailor-made analysis available under a "totality of the circumstances" approach. Under the proposed threshold test, for example, an employee might reveal a breach of public trust in a particularly disruptive manner. If that occurred, a court might consider a reasonability limitation on the employee's defense--that publication of the speech must be done in a reasonable manner if it is to be protected.

\footnotetext{
108 Connick, 461 US at 160.

${ }^{100}$ Pickering, 391 US at 569.
} 
Undoubtedly such accommodations to the vagaries of employer/employee relations will be required. But the search for perfection should not obscure the risk that general rules often do more harm than good. The proposed test offers a set of objective rules under which the outcomes of cases will closely approximate the outcomes under an equitable balancing of interests. 


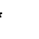

